\title{
Faith and spirituality in the meaning of life of the elderly with Chronic Kidney Disease
}

\author{
Fé e espiritualidade no sentido da vida do idoso com insuficiência renal crônica
}

Fe y espiritualidad en el significado de la vida de los ancianos con Insuficiencia Renal Crónica

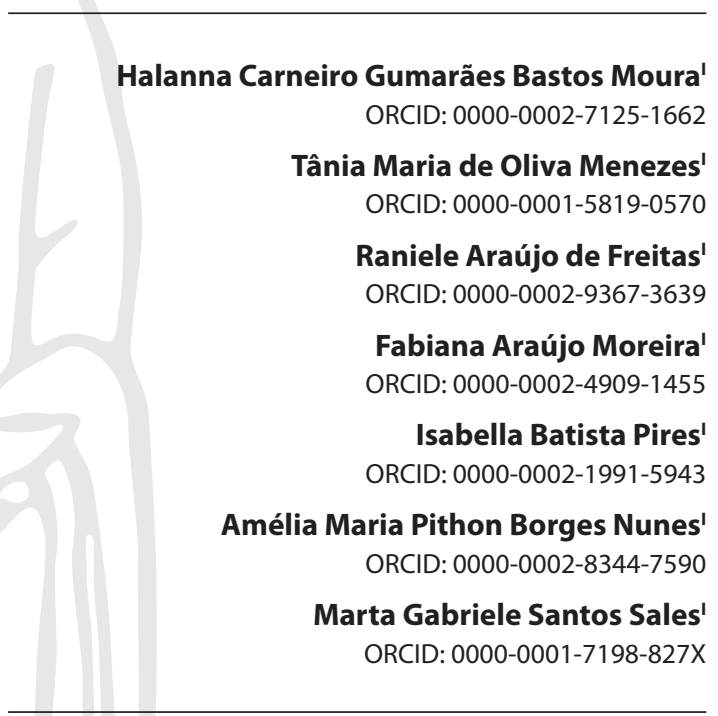

'Universidade Federal da Bahia. Salvador, Bahia, Brasil.

How to cite this article:

Moura HCGB, Menezes TMO, Freitas RA, Moreira FA

Pires IB, Nunes AMPB, et al. Faith and spirituality in the meaning of life of the elderly with chronic kidney disease.

Rev Bras Enferm. 2020;73(Suppl 3):e20190323. doi: http://dx.doi.org/10.1590/0034-7167-2019-0323

Corresponding author:

Halanna Carneiro Guimarães Bastos Moura

E-mail: halanna_bastos@hotmail.com

EDITOR IN CHIEF: ANTONIO JOSÉ DE ALMEIDA FILHO ASSOCIATE EDITOR: ELUCIR GIR

\section{ABSTRACT}

Objective: to understand faith and spirituality in the meaning of life of the elderly with Chronic Kidney Disease. Methods: a qualitative research based on Viktor Emil Frankl's Logotherapy and Existential Analysis. Twenty elderly people were interviewed between August 2018 and January 2019, between 60 and 79 years old, who underwent dialysis in a private unit, a reference in nephrology in the city of Salvador, Bahia, Brazil. Results: two categories of analysis emerged: Meaning of faith in the lived of the elderly with Chronic Kidney Disease; Faith as a forerunner of the meaning of life. Final considerations: faith and spirituality were understood as a fundamental foundation in the search for the meaning of the study participants' lives, besides unveiling itself as an important strategy of resilience to the experienced of the elderly person with Chronic Kidney Disease.

Descriptors: Elderly; Spirituality; Religion; Chronic Kidney Disease; Nursing.

\section{RESUMO}

Objetivo: compreender a fé e a espiritualidade no sentido da vida do idoso com Insuficiência Renal Crônica. Métodos: trata-se de uma pesquisa qualitativa fundamentada na logoterapia e Análise Existencial de Viktor Emil Frankl. Foram entrevistadas 20 pessoas idosas, entre agosto de 2018 e janeiro de 2019, com idade entre 60 e 79 anos, que realizam hemodiálise em uma unidade privada, referência em Nefrologia na cidade de Salvador, Bahia, Brasil. Resultados: desvelaram-se duas categorias de análise: Significado da fé no vivido do idoso com insuficiência renal crônica; Fé como precursora do sentido da vida. Considerações finais: a fé e a espiritualidade foram compreendidas como alicerce fundamental na busca do sentido da vida dos participantes do estudo, além de se desvelar como importante estratégia de resiliência frente ao vivido da pessoa idosa com Insuficiência Renal Crônica.

Descritores: Idoso; Espiritualidade; Religião; Insuficiência Renal Crônica; Enfermagem.

\section{RESUMEN}

Objetivo: comprender la fe y la espiritualidad en el sentido de la vida de los ancianos con Insuficiencia Renal Crónica. Métodos: es una investigación cualitativa basada en la logoterapia y el Análisis Existencial de Viktor Emil Frankl. Se entrevistó a veinte personas mayores, entre agosto de 2018 y enero de 2019, con edades entre 60 y 79 años, sometidas a hemodiálisis en una unidad privada, una referencia en Nefrología en la ciudad de Salvador, Bahía, Brasil. Resultados: se revelaron dos categorías de análisis: significado de la fe en la experiencia de los ancianos con insuficiencia renal crónica; La fe como precursora del sentido de la vida. Consideraciones finales: la fe y la espiritualidad se entendieron como una base fundamental en la búsqueda del significado de la vida de los participantes del estudio, además de ser reveladas como una estrategia de resiliencia importante frente a la experiencia de los ancianos con Insuficiencia Renal Crónica.

Descriptores: Anciano; Espiritualidad; Religión; Insuficiencia Renal Crónica; Enfermería. 


\section{INTRODUCTION}

Population ageing is a new challenge for today's world, both in developed and developing countries. Facing ageing is urgent, especially in Brazil, which already has an important number of elderly people, with a tendency to an increasing percentage in the coming years ${ }^{(1-2)}$.

Given this demographic change and the whole context it brings with it, it is necessary not only to reorganize the levels of care to meet the specific demands of this population, but to innovate and take as a basis experiences of other countries that experience ageing with greater structures, especially in areas involving health. At this level of change, chronic diseases emerge, bringing to light the epidemiological transition and the need for socioeconomic restructuring ${ }^{(2)}$.

Such changes significantly modify the health profile of the population, now with the presence of Chronic Noncommunicable Diseases (CNCDs), bringing impacts on quality of life and health expenditures, either through more costly health plans, or by the greater number of hospitalizations or use of high-cost drugs for a long period of time ${ }^{(3-4)}$

Among the CNCDs is Chronic Kidney Disease (CKD), which has been presented as an object of great concern in the health field, due to impairment in morbidity and mortality, arising indistinctly in both men and women, in an increasingly low age group ${ }^{(5)}$. The Brazilian Society of Nephrology's annual report shows a tendency to an overall increase in the number of patients on chronic dialysis, representing an increase of 31,500 patients in the last five years. Percentage of dialysis patients was higher in the age group of adults and the elderly, with $65.7 \%$ in the age group between 20 and 64 years old, $21.8 \%$ between 65 and 74 years old, and $11.2 \%$ at 75 years and over ${ }^{(6)}$.

With CKD, elderly people go through a process of alteration, beginning with coping with the diagnosis of a disease without cure, following with the need to perform therapeutic regimen, living with the change in daily life, understanding losses in social life, leisure, work, and living with other people. They become, therefore, human beings with their unique way of life, permeated by characteristics and beliefs of their own, besides facing the challenges of the process of illness such as undergoing treatment at least three times a week ${ }^{(7-8)}$.

Therefore, it is perceived that the irreversible character of CKD, associated with its high mortality rate, can sometimes awaken in people and their family members the reformulation of the principles related to life. They find a new meaning to their existence and knowledge, with adaptation to the new daily reality, which requires alternatives in the face of understanding the chronicity and its possible consequences ${ }^{(9)}$.

In addition to biological/physical, spirituality, and religiosity occupy a prominent place in the lives of elderly people with CKD, being able to explain to them the meaning of life. In this group of people, access to spiritual dimension contributes to improvement of QoL providing well-being, reducing levels of anguish and feeling of uselessness, besides favoring development of resilience in difficult situations inherent to ageing such as physical and emotional losses (10-11). $^{\text {. }}$

Although closely related, but with meanings that differ from each other, especially to what is related to their practice, spirituality and religiosity can act as constructs capable of providing subsidies to the elderly person coping with CKD and all its demands. Spirituality and religiosity transit from concreteness of existence to its deepest and subjective aspects, making it challenging to integrate spiritual and religious dimensions into health care ${ }^{(12-13)}$.

The experience of spirituality and religiosity can promote search for the meaning of existence from the practices used, notions of the sacred and the exercise of faith. Faith as an expressive representation of both may also favor search for the meaning of life in everyday situations of human beings, or even in the most intimate and subjective search for its singularity, which coincide with ultimate meaning ${ }^{(12,14)}$.

Ultimate meaning is characterized by the sense of the whole, of the meaning of life as a whole. The way for man to find his utimate meaning may be linked to existential analysis, or through vital situations such as CKD. It can also be observed in the essential transience of human existence, in its attitude towards life and in situations of suffering such as death and existential anguish. The scope of the ultimate sense of human life becomes possible through continuous exercise of faith, understood as a transcendental category, which provides the idea of the meaning of life in the face of the ultimate questions of existence ${ }^{(14-15)}$.

Although it has several meanings, faith consents to the will of meaning of each person, and in spiritual settings, it can be glimpsed as a direction, a trust of the man turned and deposited in the transcendent, in the sacred, which can give new meanings to their lives ${ }^{(12)}$.

\section{OBJECTIVE}

To understand faith and spirituality in the meaning of life of the elderly with CKD.

\section{METHODS}

\section{Ethical aspects}

The Research Ethics and Committee of the hospital, study site, approved the study. It was conducted according to the standards of research involving human beings, described in Resolution 466/12, $510 / 16$ and 580/17, of the Brazilian National Research Ethics Council (Conselho Nacional de Ética em Pesquisa) ${ }^{(16-18)}$. The reports were collected after signing the Informed Consent Term. To ensure anonymity, fictitious names of stars were assigned to the participants.

\section{Type of study}

This qualitative research of phenomenological approach was based on Viktor Frankl's Existential Analysis ${ }^{(14,19)}$, guided by COREQ ${ }^{(20)}$

\section{Study setting}

The study was conducted at a nephrology unit of a private hospital in the city of Salvador, state of Bahia, Brazil, from August 2018 to January 2019. The chosen unit is based in a peripheral neighborhood of the city, where patients undergo dialysis and are followed by a multidisciplinary team composed of physicians, 
nurses, nursing technicians, nutritionists, social workers, and physiotherapists. In addition to dialysis visits, this unit has a peritoneal dialysis and kidney transplantation program, serving about 250 transplant patients in its post-transplant outpatient clinic.

\section{Study participants}

To participate in the study, people aged 60 years and older who underwent dialysis treatment at the institution three times a week during the four-hour period were selected. The choice of participants followed the following criteria: 1) Inclusion: elderly people who have been undergoing dialysis three times a week for at least six months, due to a better experience of therapy; and who could verbally communicate; 2 ) Exclusion: elderly people who presented hemodynamic instability during data collection due to various issues. It is noteworthy that there was a refusal to research, due to malaise at the time of the approach.

Since it is a phenomenological study, the number of participants occurred through regularity of the discourses and when the studied phenomenon was unveiled. Before starting the interviews, some moments of approximation were conducted by the researcher, so that a favorable environment for the development of the research was created, considering empathy as the facilitator of understanding, without the need to live the experience of the other ${ }^{(21)}$.

\section{Data collection and organization}

The selected elderly participated in the phenomenological interview, which constitutes an existential approach between two people, in order to be able to understand a phenomenon from the perspective of those who are experiencing it and meaning ${ }^{(22)}$, containing two open-ended and triggering questions: what do you think faith is? How have you lived spirituality in your daily life after the diagnosis of kidney disease?

The interviews took place at the unit, on previously scheduled days, at the time of dialysis therapy, because many patients are from the countryside of of Bahia and have established times for return, thus avoiding moments of anxiety and concern about the schedule.

The phenomenological space was reserved, ensuring privacy and confidentiality of the information, which was recorded by an audio program on mobile device, Android system, and later transcribed in full.

\section{Data analysis}

To systematize and understand the data obtained, and assuming that it is not possible to unlink philosophical trends, intentions and worldview that we consider of our own experiences as being-in-the-world, it is necessary to design phenomenological analysis, applied to this research from a reflection guided by a dynamic process of conception of man, world and universe ${ }^{(23)}$.

Thus, it was decided to treat the data obtained through those proposed by Giorgi and adapted by Vietta ${ }^{(23)}$, namely: 1) Careful reading of the statements to rescue the meanings; 2 ) New reading identifying the units of meaning and locutions of effect, where the experiences are contained; 3 ) Identification and classification of aspects that may present content convergences; 4) Groupings of meanings identified into categories; 5) Listing of these groupings in representative tables, for a better visualization and understanding of the results; 6) Analysis of significant data, based on the interpretation of content with Viktor Frankl's Existential Analysis ${ }^{(19)}$.

\section{RESULTS}

\section{Characterization of participants}

Twenty elderly people with CKD participated in the study, ages ranged from 60 to 79 years, and of these, fourteen are male (Acamar, Regulus, Sham, Castor, Deneb, Sirius, Sol, Izar, Hadar, Baham, Albali, Alcor, Jih, Kraz) and six female (Maia, Vega, Alcyone, Alya, Lucida, David). As for marital status, 14 are married, two widowed, two single and two separated. The level of education varied from illiteracy to incomplete high school, with only four participants having a college degree.

Concerning the reported comorbidities, five have Systemic Hypertension (SH); 10 have SH and Diabetes Mellitus (DM); five participants did not report these pathologies. Among the CNCDs that potentiate CKD, SH and DM stood out. In relation to religion, 12 participants are Catholics; five are Evangelicals; one is Jehovah's witness; one is from the Messianic Church; and one is from Candomblé (Candomblé is an African-originated or Afro-Brazilian religion, practiced mainly in Brazil by the povo de santo (people of the saint). It is a mixture of traditional Yoruba, Fon, and Bantu beliefs which originated from different regions in Africa), however, also sympathizes with Catholicism.

The statements evidenced faith as a trigger for the encounter of the meaning of life for the elderly person with CKD, and this phenomenon was unveiled in the following categories:

\section{Meaning of faith in the experience of the elderly with Chronic Kidney Disease}

When faced with CKD and the need for dialysis to maintain life, the elderly with CKD begins to face a process of acceptance and resignification of its existence, requiring the use of resources that help them in daily life with the disease. Faith was pointed out as one of these resources and when asked what their lives mean, they reported:

Faith is everything you believe in, without having to touch or take it. Faith is abstract, isn't it? So, everything that you believe with conviction, but that you can't take or touch, I think it's true faith. (Acamar, man, Catholic, 62 years old)

Faith is believing. I believe and have faith that my kidney will be fine. (Regulus, man, Catholic, 68 years old)

Faith is that thing that comes from the heart. We have faith because God touches the heart to give us faith. (Sun, man, Evangelical, 72 years old)

Faith is what you believe. I only have one thing to tell you "I have faith in God. My faith is in God". (Izar, man, Catholic, 79 years old) 
The definitions of faith brought by Acamar, Regulus, Sun, and Izar involve believing in their subjectivity, what cannot be touched, but felt, promoting hope. Faith involves the deepest beliefs of being in what is true to each one, moving expectations and confidence in the future, as evidenced in the following statements:

Faith is a certain expectation that we will acquire in proportion as we have knowledge to have a hope for the future. (Sham, man, Jehovah's witness, 66 years old)

Faith is a magical moment, it is a time when you approach metaphysical things. (Deneb, man, Catholic, 74 years old)

Sham and Deneb's discourses discuss faith directly related to a belief in something far from evidence, but closely related to being, hopes and concepts in its subjectivity.

Sham deepens deeper into the concept of faith, when it prints the ideals of metaphysics with its feelings and experiences in the face of its credulity, i.e. it transcends its reality of sensitive experience through reflections beyond physics, through the essence of things and their experiences.

Other participants, on the other hand, mean faith:

Faith is to love God, and everything you ask for is achieved. If I didn't have faith, I wouldn't be here anymore, because the way I was, I thought that faith in Jesus Christ would never come back, my faith with him, but he did, so for me it's everything. (Maia, woman, Catholic, 61 years old)

Faith is the person to believe. It is believing that there is a God who can heal and do what he wants and wants to understand. He is the one who loves until the end, and I have faith. I just don't have the faith to go back to normal, as I was before, active, teacher, worker, who didn't depend on anyone. (Alya, woman, Catholic, 63 years old)

I can't explain it in words, but I have faith in God, that I'm here, but I still have faith that he will solve this problem of mine. Or by the doctors, or by himself, do you understand? Because when he wants, he does the work, or by himself, or he does it through doctors, I'm sure of it. (Alcyone, woman, Evangelical, 76 years old)

The participants' understanding of faith is related to belief in God and the possibility of him representing strength, overcoming, and momentum in the daily struggle for disease and continuity of his existence.

Maia shows that faith in Jesus represented his livelihood since the diagnosis of CKD, as well as in coping with daily life. Alya defines faith as believing in God, the one capable of transforming everything into the name of love. However, she understands her illness as incurable and as a complicating factor in her previously established routines. Alcyone expresses faith as trust in a possible cure, even in the face of a disease with no possibility of cure, for for her faith is directly related to God and He can all, even in the face of the impossible.

\section{Faith as a precursor to the meaning of life}

As a resource of coping and support, faith appears in the lives of participants as precepts and consistent values about what they believe and trust, even in difficult moments related to the mishaps brought by the disease:
I think there are moments of faith, there are moments of doubt and there are moments in the lives of people that we live in hope. (Deneb, man, Catholic, 74 years old)

[...] faith becomes the north of the person's life. (Kraz, man, Catholic, 70 years old)

You must have faith, living and true faith. As I am really facing and thank God, if it weren't for this God that I have this faith, I don't think I would exist, no, I wouldn't take it. (Vega, woman, Catholic, 65 years old)

The above reports show moments when the elderly person with CKD refers to doubts and difficulties in the face of the adversities imposed by the disease, and faith is presented as support and support in search of hope to continue living.

At times, there is a contradiction between saying that you have faith and actually having according to Vega:

We have to accept what happens to us, don't we? When we say that we have faith, we have to have faith from beginning to end. In this case, we say we have faith. When tribulations, diseases come, we begin to despair and then Ithinkitis a dead faith. (Vega, woman, Catholic, 65 years old)

Vega uses the term "dead faith," what she designates as faith that does not help them in times of suffering and despair. She strongly argues that faith must exist even in the most painful moments, which confirms the concept of source of coping and life support. Also, view as support, as Hadar:

It's up to me. It is my faith. If I were not in the presence of God and a supernatural faith, I think I would not be alive. I wouldn't be alive, I wouldn't. It strengthens me greatly, the presence of God in my life. It is that lifts me every day, helps me to breathe, walk, talk, see. (HADAR, man, evangelical, 67 years old)

Hadar refers to faith as something that lifts him up and leaves him willing to fight daily for his life, even before CKD. Faith arises in the process of illness of the elderly person with CKD as a source of help, so that they can continue to live and find their meaning of life, even in situations that bring pain, suffering and anguish.

In the settings of spiritual experiences, faith is seen as a direction, a trust of the human being placed in the sacred, which can lead to resignifying the meaning of their lives, as reported:

Either you cling to something, in my case spirituality, faith, or you don't walk towards, understand? I remain having the same energy I had before, and every day I thank God, because without him there is no life. I feel very good. (Castor, man, evangelical, 65 years old)

My life is about singing and laughing. I do not like to think of sadness, because if I think of sadness, I think I die. Because I'm sick mostly. I think I have no cure, but I have faith in God. (David, woman, Catholic, 66 years old)

I usually joke by saying I'Il live until at least ninety years. I'm hoping that this is it, I have faith that this will happen. I will have a long life. (Albali, man, Catholic, 79 years old)

Castor refers to his faith linked to spirituality as one is contained in the other. Assuming that spirituality is independent 
of religiosity, faith exists in what is the belief and trust of each one. David knows that the cure for his illness does not exist, but it keeps faith alive and active to continue living, singing, and smiling. Albali reveals that he has faith and wishes to have a long and happy life, remaining confident.

I live more in faith, don't I? Asking God first, to the orixás, to give me strength, wisdom and continue here. (Lucida, woman, Candomblecist (from Candomblé), 70 years old)

Faith, I believe it is what we believe we do not see. Today, every day it gets bigger. Before I did not think so much. When I was younger, I was healthy and all. I used to walk back and forth, do things. I wasn't sick. For me, I knew that there was faith, because my whole family was always religious, but I did not have so much belief. (Sirius, man, evangelical, 64 years old)

Lucida considers faith as a source of strength and wisdom. Sirius comments that, through the disease, his faith could be reborn and become stronger in coping with daily life with CKD. By strengthening themselves in faith, the elderly with CKD experience the process of illness with more tranquility and less suffering, envisioning in it the strength he needs to seek new senses and meanings for his life.

\section{DISCUSSION}

Analysis of the statements made it possible to understand faith and spirituality in the meaning of life for elderly people with CKD. The unveiling of the phenomenon occurred in its true essence, the way it really shows itself and how it really is. Faith was presented as a precursor to the meaning of life, besides being experienced as an important strategy of resilience for the participants.

The human being is seen in the analytical-existential perspective as an anthropological unit, endowed with body or somatic dimension, psychic dimension and the noetic or spiritual dimension. Spirituality of man does not become only a characteristic for the distinction of man, as well as the bodily and psychic element. On the other hand, the spiritual dimension is something that distinguishes man, something that is only up to him and that comes to him for the first time ${ }^{(15,24)}$.

In the biopsychospiritual dimensions, the determining constituent that defines the human being as a person is the experience in unconscious spirituality. He is characterized as the true deep person, or also called by a spiritual person, i.e. the most profound existential-spiritual. Thus, the spiritual person is not only optionally, but necessarily unconscious ${ }^{(14,25)}$.

Understanding the spiritual and comprehensive world of three-dimensionality, where human beings experience, through different modalities of sensitive perception, their somatic condition as a structuring dimension for their experiences, provides an opportunity for their inclusion as being in the world, from the world and for the world, but that want to launch themselves beyond the world Thus, one can only speak of something existential, from the given be-in-the-world ${ }^{(26)}$.

Nevertheless, the statements revealed that spirituality is an important construct for the elderly person who experiences the process of CKD as a being-in-the-world, who experiences a process of reformulation of life habits and at the same time suffers from the anguish, deprivation sandand afflictions caused by these restructurings.

Spirituality is directly related to personal encounter by the meaning of existence and the fulfillment of spiritual needs is directly linked to the search for fullness and the possibility of transcending existence. Understanding the spiritual dimension, even in different perspectives and connotations, becomes essential for better experience, since it enables search for a broader meaning of life, through a greater sense of connection with the universe ${ }^{(15,27)}$.

CKD requires changes in the daily life of the participants, because they live moments of suffering and spiritual anguish, and most could reinvent new ways of resignifying their lives. The fact is that every human being, even in times of intense suffering or lack of hope, can find their meaning of life, since they possess a will of meaning, the driving force of human life $\mathrm{e}^{(19)}$.

The search for the meaning of life can cause doubts to the elderly. Only knowledge and certainty of this sense are not enough to answer these questions and solve the demands of the situations. For existential analysis, the only instrument capable of elucidating this object is faith. It is not a way of thinking in which reality is subtracted, but rather a mode of reflection in which existentiality of the thinker ${ }^{(14)}$ is added.

Faith arises in the life of the participants being characterized as a transcendental category, which signals their mobilization for something beyond and that carries their life of meaning in a situation of suffering. Faith behaves in the context of the elderly person with CKD as one of the expressions of spirituality, which may favor the search for the meaning of life in everyday situations, or even in challenging moments and loaded with feelings ${ }^{(12)}$.

The definition of faith permeates the intimate and absolute experience of each individual according to their own convictions, ideas or hypotheses, and are directly related to their personal achievements developed through solidity of their own existence ${ }^{(12)}$. Transcendence, on the other hand, is closely related to what permeates our own moral conscience. Deepening the meaning beyond the philosophical and entering into spiritual means, transcendence is closely related to the immortal and essential, standing out bodily limits and establishing an attempt at closeness to God or his Superior ${ }^{(14)}$

Faith and transcendence proved significant to the participants and are related to strength to face the moment of discovery and treatment of the disease, until the moment when these people think they would no longer be able to overcome them ${ }^{(28)}$. In their answers, faith was founded on an omnipotent God, who possesses the power to heal afflicted illnesses and help. Most of the statements show that faith has not been decontextualized from the religious universe, such as the citation of the "supernatural faith", elucidated mainly in evangelical doctrines and that it has its development in a purely spiritual world, the only link of communication between the physical and spiritual world. Faith is almost always conceived as protection, trust, support, and reach of grace ${ }^{(29)}$.

The faith revealed by the participants also demonstrated an intrinsic relationship of their deepest Self and a Transcendent ${ }^{(26)}$, coming to be understood as a way of ensuring the meaning of life in the face of the ultimate questions of existence. It can be seen 
as a direction, a trust of the human being turned and deposited to the sacred, which can mean his life ${ }^{(12)}$. Thus, it becomes one of the locutions of spirituality, and can be experienced from it or from religiosity and its practices, especially from awakening to what motivates, the will of ultimate meaning ${ }^{(14)}$.

Ultimate meaning, in existential analysis, is the meaning of life as a whole ${ }^{(15)}$. It is difficult for man to understand on purely rational ground, but rather on purely existential soil, through all his being, i.e. through faith. The issue of ultimate meaning is directly related to faith, which is directly related to a spiritual consciousness ${ }^{(30)}$.

Unconditional faith and love are the main means of understanding the ultimate meaning ${ }^{(26)}$. Although the participants demonstrated suffering with the disease, they also evidenced the exercise of faith in daily life in overcoming, in love, in existence and in God, being revealed and defended by Frank| ${ }^{(14,19,30)}$ as an unconscious tendency of man towards God, the unconscious God.

God as a source of faith is the ultimate meaning of human existence, dialoguing with man when he comes into contact with his own moral conscience ${ }^{(14)}$. Thus, it is noticeable that there is a deep and intimate relationship between God and elderly people who experience CKD, which transcends in its intersubjectivity. In addition to an essential support in the health-disease process, the relationship with God or the Sacred means self-knowledge about oneself and their relationships, thus configuring the spiritual person in their life-world.

\section{Study limitations}

The limitation of the study refers to the impossibility of generalizing its results to the entire elderly population, since they represent elderly people with CKD followed up in a nephrology unit in Bahia.
However, depth of the results on faith, spirituality, and meaning of life can be applied to people who experience situations of chronic diseases, such as that of the participants of this study.

\section{Contributions to nursing}

The results and the foundation of this study may awaken in health professionals, especially nurses, reflection on their clinical practice in care for the elderly who experience CKD. In this perspective, considering faith and spirituality as important strategies of resilience, which have the capacity to give a new meaning to the meaning of life, ensure multidimensional care, based on the biopsychosociospiritual aspects in the totality of being.

\section{FINAL CONSIDERATIONS}

Faith and spirituality were unveiled as important strategies of resilience in the experience of elderly people with CKD, besides acting as a fundamental foundation in the search for the meaning of life of these individuals, after the changes imposed by the disease. Therefore, faith and spirituality present themselves as a source of strength, overcoming and foundation before what cannot be modified, but rather restructured and with new meanings and meanings.-

\section{ACKNOWLEDGMENTS}

Special recognition to those who contributed beautifully to the conclusion of this article, and a special thanks to the participants of this study who set out to welcome us with such love and affection.

\section{REFERENCES}

1. Melo LA, Ferreira, LMBM, Santos MM, Lima KC. Socioeconomic, regional and demographic factors related to population ageing. Rev Bras Geriatr Gerontol[Internet]. 2017 [cited 2019 Apr 03];20(4):494-502. Available from: https://www.scielo.br/pdf/rbgg/v20n4/1981-2256rbgg-20-04-00493.pdf

2. Miranda GMD, Mendes ACG, Silva, ALA. Population aging in Brazil: current and future social challenges and consequences. Rev Bras Geriatr Gerontol [Internet]. 2016[cited 2019 Apr 03];19(3):507-19. Available from: https://www.scielo.br/pdf/rbgg/v19n3/1809-9823rbgg-19-03-00507.pdf

3. Pereira DS, Nogueira JAD, Silva CAB. Quality of life and the health status of elderly persons: a population-based study in the central sertão of Ceará. Rev Bras Geriatr Gerontol[Internet]. 2015[cited 2019 Apr 02];18(4):893-908. Available from: http://www.scielo.br/pdf/rbgg/ v18n4/1809-9823-rbgg-18-04-00893.pdf

4. Reis CS, Noronha K, Wajnman S. Envelhecimento populacional e gastos com internação do SUS: uma análise realizada para o Brasil entre 2000 e 2010. Rev Bras Estud Popul[Internet]. 2016[cited 2019 Apr 02];33(3):591-612. Available from: https://www.scielo.br/pdf/rbepop/ v33n3/0102-3098-rbepop-33-03-00591.pdf

5. Xavier BLS, Santos I, Almeida RF, Clos AC, Santos MT. Individual and clinical characteristics of clients with chronic kidney disease on renal replacement therapy. Rev Enferm UERJ[Internet]. 2014[cited 2019 Apr 02];33(3):314-20. Available from: https://www.e-publicacoes.uerj.br/ index.php/enfermagemuerj/article/view/13683

6. Sesso RC, Lopes AA, Thome FS, Lugon JR, Martins CT. Brazilian Chronic Dialysis Survey 2016. J Bras Nefrol[Internet]. 2016[cited 2019 Apr 01];39(3):261-66. Available from: https://www.scielo.br/pdf/jbn/v39n3/0101-2800-jbn-39-03-0261.pdf

7. Machado FS, Vianna LG, Coelho KHV, Oliveira MLC, Faleiros V, Moraes CF. Qualidade de vida de idosos submetidos à hemodiálise: uma revisão sistemática. Rev Kairós Gerontol [Internet]. 2014 [cited 2019 Apr 01];17(3):149-63. Available from: https://revistas.pucsp.br/kairos/ article/view/21914/16111

8. Pilger C, Santos ROP, Lentsck MH, Marques S, Kusumota L. Spiritual well-being and quality of life of older adults in hemodialysis. Rev 
Faith and spirituality in the meaning of life of the elderly with chronic kidney disease Moura HCGB, Menezes TMO, Freitas RA, Moreira FA, Pires IB, Nunes AMPB, et al.

Bras Enferm[Internet]. 2017 [cited 2019 Apr 02];70(4):689-96. Available from: https://www.scielo.br/pdf/reben/v70n4/0034-7167reben-70-04-0689.pdf

9. Hoelzel F, Morales BCV. A vontade de sentido: criando novas possibilidades de vida. Rev Logos Exist[Internet]. 2017 [cited 2019 Apr 01];6(1):53-68. Available from: http://www.periodicos.ufpb.br/ojs/index.php/le/issue/view/2084/showToc

10. Cruz JP, Colet PC, Qubeilat H, Al-Otaibi J, Coronel El, Suminta RC. Religiosity and health-related quality of life: a cross-sectional study on Filipino Christian hemodialysis patients. J Relig Health[Internet]. 2016[cited 2019 Apr 02];55(3):895-908. Available from: https://www.ncbi. nlm.nih.gov/pubmed/26289995

11. Nery BLS, Cruz KCT, Faustino AM, Santos CTB. Vulnerabilities, depression, and religiosity in the elderly hospitalized in an emergency unit. Rev Gaúcha Enferm[Internet]. 2018[cited 2019 Apr 02];39(20):1-9. Available from: https://www.scielo.br/pdf/rgenf/v39/en_1983-1447-rgenf39-01-e2017-0184.pdf

12. Corrêa DA. Fé e sentido de vida: reflexões a partir do paradigma analítico-existencial frankliano. Rev Logos Exist [Internet]. 2017 [cited 2019 Apr 02];6(1):2-14. Available from: http://www.periodicos.ufpb.br/ojs/index.php/le/issue/view/2084/showToc

13. Esperandio MRG, Ladd KL. I heard the voice. I felt the presence": prayer, health and implications for clinical practice. Relig [Internet]. 2015[cited 2019 Apr 02];6(2):670-85. Available from: https://www.academia.

edu/13051164/_I_Heard_the_Voice._I_Felt_the_Presence_Prayer_Health_and_Implications_for_Clinical_Practice

14. FrankI VF. A presença ignorada de Deus. 18 ed. São Leopoldo (SP): Sinodal; Petrópolis (RJ): Vozes. 2017. p. 131.

15. Xausa IAM. A psicologia do sentido da vida. 2 ed. Campinas (SP): Vide Editorial. 2013. p. 291.

16. Ministério da Saúde (BR). Conselho Nacional de Saúde. Resolução n. 466, de 12 de dezembro de 2012. Dispõe sobre normas e diretrizes de pesquisas envolvendo seres humanos [Internet]. Brasília; 2012[cited Mar 31]. Available from: http://conselho.saude.gov.br/resolucoes/2012/ Reso466.pdf

17. Ministério da Saúde (BR). Conselho Nacional de Saúde. Resolução n. 510, de 7 de abril de 2016. Dispõe sobre as normas aplicáveis a pesquisas em Ciências Humanas e Sociais cujos procedimentos metodológicos envolvam a utilização de dados diretamente obtidos com os participantes ou de informações identificáveis ou que possam acarretar riscos maiores do que os existentes na vida cotidiana [Internet]. Brasília; 2016[cited 2019 Mar 31]. Available from: http://bvsms.saude.gov.br/bvs/saudelegis/cns/2016/res0510_07_04_2016.html

18. Ministério da Saúde (BR). Conselho Nacional de Saúde. Resolução no 580 de 22 de Março de 2018. Dispõe sobre a regulamentação do disposto no item XIII.4 da Resolução CNS n 466, de 12 de dezembro de 2012, que estabelece que as especificidades éticas das pesquisas de interesse estratégico para o Sistema Único de Saúde (SUS) [Internet]. Conselho Nacional de Saúde. Brasília, 2018[cited 2019 Apr 01]. Available from: http://conselho.saude.gov.br/resolucoes/2018/Reso580.pdf

19. FrankI VF. Em busca e sentido: um psicólogo no campo de concentração. 40 ed. São Leopoldo (SP): Sinodal; Petrópolis (RJ): Vozes. 2016. p. 184.

20. Tong A, Sainsbury P, Craig J. Consolidated criteria for reporting qualitative research (COREQ): a 32-item checklist for interviews and focus groups. Int J Qual Health Care [Internet]. 2007 [cited 2019 Mar 09];19(6):349-57. Available from: https://academic.oup.com/intqhc/ article/19/6/349/1791966

21. Paula CC, Padoin SMM, Terra MG, Souza IEO, Cabral IE. Driving modes of the interview in phenomenological research: experience report. Rev Bras Enferm[Internet]. 2014[cited 2019 Apr 04];67(3):468-72. Available from: https://www.scielo.br/pdf/reben/v67n3/0034-7167reben-67-03-0468.pdf

22. Guerrero-Castañeda RF, Menezes TMO, Ojeda-Vargas MG. Características de la entrevista fenomenológica em investigación en enfermeira. Rev Gaúcha Enferm [Internet]. 2017[cited 2019 Mar 28];38(2):1-5. Available from: https://www.scielo.br/pdf/rgenf/v38n2/en_0102-6933rgenf-1983-144720170267458.pdf

23. Vietta EP. Configuração triádica, humanista-existencial-personalista: uma abordagem teórica-metodológica de aplicação nas pesquisas de enfermagem psiquiátrica e saúde mental. Rev Latino-Am Enfermagem [Internet]. 1995[cited 2019 Mar 28];3(1):31-43. Available from: http:// www.scielo.br/pdf/rlae/v3n1/v3n1a04.pdf

24. FrankI VE. Logoterapia e análise existencial: texto de seis décadas. 3 ed. Rio de Janeiro (RJ): Forense Universitária. 2017. p. 332.

25. Meireles MVC. A pessoa espiritual e sua consciência moral. O ser religioso e a relação com a dimensão existencial. Rev Logos Exist[Internet]. 2015[cited 2019 Mar 28];4(2):117-29. Available from: http://www.periodicos.ufpb.br/ojs/index.php/le/article/view/22844

26. Dittrich MG. O ser religioso e a relação com a dimensão existencial. Rev Logos Exist [Internet]. 2015[cited 2019 Mar 28];4(2):117-29. Available from: http://www.periodicos.ufpb.br/ojs/index.php/le/issue/view/1687/showToc

27. Rocha RCNP, Pereira ER, Silva RMCRA, Medeiros AYBBV, Refrande SM, Refrande NA. Spiritual needs experienced by the patient's family caregiver under Oncology palliative care. Rev Bras Enferm[Internet]. 2018[cited 2019 Mar 28];71(Suppl6):2635-42. Available from: https:// www.scielo.br/pdf/reben/v71s6/0034-7167-reben-71-s6-2635.pdf

28. Geronasso MCH, Coelho D. A influência da religiosidade/espiritualidade na qualidade de vida das pessoas com câncer. Saúde Meio Ambient[Internet]. 2012[cited 2019 Mar 28];1(1):173-87. Available from: http://www.periodicos.unc.br/index.php/sma/article/view/227

29. Oliveira AM, Herbes NE. Espiritualidade, fé e cura: um olhar sobre a religiosidade popular. Id onLine Rev Psicol [Internet]. $2016[$ cited 2019 Sep 27];10(31):179-81. Available from: https://idonline.emnuvens.com.br/id/article/view/532/705

30. FrankI VF. A vontade de sentido: fundamentos e aplicações da logoterapia. São Paulo (SP): Paulus. 2016. p. 224. 